\title{
BIOPREPARATIONS FOR THE PRODUCTION OF ENVIRONMENTALLY SAFE FOOD - Part II
}

\author{
Tatiana Nugmanova, Lyubov Chistyakova, Iion Petra, Olga Shelepova, Vera Kondrat'eva
}

\begin{abstract}
The effectiveness of the bio fertilizer "NIKFAN" - one of the main biopreparations used in the Biologization System - was studied. This is a new modern biopreparation, which proved to be very effective for cultivating various crops in open and closed ground. In this article, as an example, the results of its application for cultivating cucumber in greenhouses are provided. The influence of the Nikfan biopreparation on the elasticity of leaves and the content of chlorophyll in them has also been confirmed.
\end{abstract}

Key words: biopreparation, vegetables, cucumber, growth stimulation

\section{INTRODUCTION}

BIOIN-NOVO LLC, the developer of the biopreparation "Biofertilizer "Nikfan", has continued conducting its second year biological efficiency test on cucumber of various breeding variants at the Farming Enterprise "Poisk", Moscow Region, Russia. Biofertilizer "Nikfan" is designed to increase immunity, stimulate growth and development of plants and is produced by cultivating endophytic fungi [1-5]. It has already been tested on a wide range of plants: vegetables, cereals, fruit trees, and shrubs, flowers, and herbs in different countries: Russia, Colombia, Africa, India, China, Bulgaria, Kazakhstan, and Lithuania [3-7].

The main effects observed after the treatment of seeds and then the vegetative mass of plants are as follows:

- increased germination and germinating capacity of seeds and tubers;

- increase in root formation (length and thickness of roots, the number of thin rootlets);

- increase in the size of fruits, corms, increase in the number of large fruits;

- enhanced nitrogen fixation, photosynthesis, leaf surface of plants and, as a result, increased yields;

- increased frost resistance and drought resistance;

- increased resistance to fungal diseases and reduced number of chemical fungicides applied;

- improved growth of rootstock and graft;

- increased quality of plants (increase in the gluten content of grain, technological properties of fiber, sugar content, vitamins);
- increased growth of shoots, bushiness, decrease in the lag in the ovaries;

- accelerated ripening by 1.5-2 weeks.

The second year test was aimed at confirming the effect of the Nikfan biopreparation obtained earlier on the Farming Enterprise "Poisk", Moscow Region, Russia. The tests were carried out in polycarbonate heated ground greenhouses from December 27, 2016 to May 25, 2017. The aim of the studies was to confirm the high efficiency of the Nikfan biopreparation and its influence on the growth and development of cucumber seed plants.

\section{MATERIALS AND METHODS}

At the beginning of the cucumber growing process, the seeds were treated with a working solution of the biopreparation in a concentration of 8 $\mathrm{ml}$ per liter of water for 1 hour. In the control, water was used instead of the preparation. The first treatment of plants was carried out in Phase 1-2 of the leaves: before planting in the greenhouse, the concentration of the preparation was $3 \mathrm{ml} / 1$ of water, after planting in the greenhouse on a permanent place $-8 \mathrm{ml} / \mathrm{l}$. Treatments were conducted every 10 days. To determine the functional state of the leaf cells membranes, the $0.5 \mathrm{~cm}$ diameter samples thereof were placed in bidistillate, incubated for 24 hours in a thermostat at $26^{\circ} \mathrm{C}$, and measured the conductivity of the eluate on a conductivity meter. Then, the content of $\mathrm{K}^{+}$and $\mathrm{Na}^{+}$ions in the eluate was determined potentiometrically using ionselective electrodes. Photosynthetic leave pigments were analyzed by spectrophotometric method according to the conventional procedure [8]. 


\section{RESULTS AND DISCUSSION}

During growth of the cucumber plants, it was found that the seedlings were characterized by a more saturated green color, looked stronger and healthier in

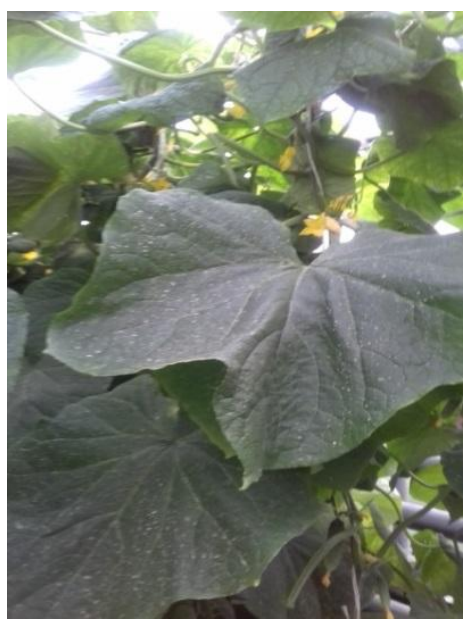

A comparison with the plants from the control group as shown in Fig. 1. Table 1 shows the scheme of test options that includes treatment of both the seed and the vegetative plants in their different variants.

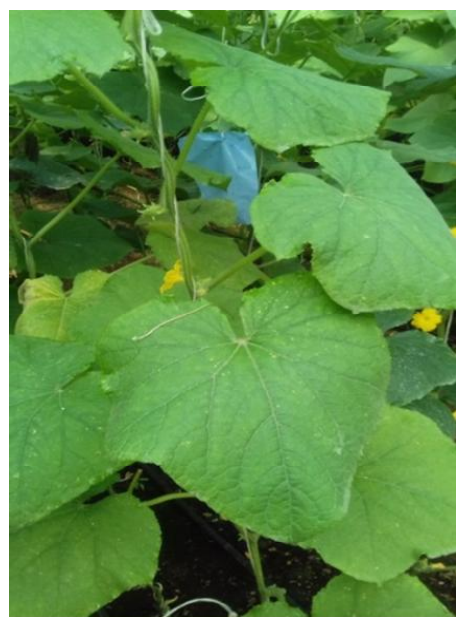

B

Fig.1 Cucumber leaves treated with Nikfan (A) and without any treatment (B)

Table 1. Plant Treatment Scheme

\begin{tabular}{|c|c|c|c|c|c|c|c|c|}
\hline \multirow{2}{*}{ Stage } & \multicolumn{7}{|c|}{ Options } \\
\cline { 2 - 9 } & 1 & 2 & 3 & 4 & 5 & 6 & 7 & 8 \\
\hline Seeds & + & + & + & - & - & - & + & - \\
\hline Tubers & - & + & + & + & + & - & - & - \\
\hline Plants & - & - & + & - & + & + & + & - \\
\hline
\end{tabular}

$«+_{»}-$ treatment, «-»- without treatment.

As a result of the treatment of plants, the following parameters were registered: the number of fruits, the total weight of the fruit, and the average weight of the fruit. Accounting was conducted every 2-3 days. Table 2 summarizes the results. In addition, leaves were taken from the central part of the stem to analyze the chlorophyll content and the electrolyte ions output to determine the elasticity of the leaves. The results are shown in Tables 3 and 4 .

Table 2. Results of biopreparation Nikfan application in cucumber seed-growing

\begin{tabular}{|c|c|c|}
\hline \multicolumn{3}{|c|}{ Biopreparation Nikfan, Batch № 25 } \\
\hline $\begin{array}{c}\text { Number of fruits, pcs. } \\
\text { (Percentage of excess vs control) }\end{array}$ & Fruit weight, g & Average weight of 1 fruit, g \\
\hline $830(27,6 \%)$ & $85575(46,4 \%)$ & $102.8(27,7 \%)$ \\
\hline \multicolumn{3}{|c|}{ Control } \\
\hline 650 & 58430 & 80,45 \\
\hline
\end{tabular}




\begin{tabular}{|c|c|c|}
\hline \multicolumn{3}{|c|}{ Biopreparation Nikfan, Batch № 9} \\
\hline $1128(49,8 \%)$ & $86875(55,9 \%)$ & $74.6(6,1 \%)$ \\
\hline 753 & Control & 70,3 \\
\hline \multicolumn{3}{|c|}{55720} \\
\hline $1958(39,5 \%)$ & TOTAL: \\
\hline 1403 & $172450(51,0 \%)$ & $88.7(75,3 \%)$ \\
\hline
\end{tabular}

Table 3. Permeability of the cell wall and content of $\mathrm{K}^{+}$and $\mathrm{Na}^{+}$ions

\begin{tabular}{|c|c|c|c|c|}
\hline \multirow[t]{3}{*}{ Parameter } & \multirow[t]{3}{*}{ Option } & \multicolumn{2}{|c|}{$\begin{array}{l}\text { Treated with Nikfan, } \\
\text { Batch No. } 9\end{array}$} & $\begin{array}{c}\text { Treated with } \\
\text { Nikfan, Batch } \\
\text { No. } 25 \\
\end{array}$ \\
\hline & & \multicolumn{3}{|c|}{ Cucumber Variety } \\
\hline & & "Express" & "Ekipazh" & "Trapezny" \\
\hline \multirow{2}{*}{$\begin{array}{l}\text { Electrolytes ions output in } \\
\text { the eluate relative to their } \\
\text { total content in cells, } \%\end{array}$} & Control & 29.17 & 34.49 & 34.29 \\
\hline & Active & 29.04 & 31.98 & 31.74 \\
\hline \multirow{2}{*}{$\begin{array}{l}\text { Ions } \mathrm{K}^{+} \text {output in the eluate } \\
\text { relative to their total content } \\
\text { in cells }, \%\end{array}$} & Control & 2.60 & 2.90 & 3.36 \\
\hline & Active & 1.60 & 2.18 & 2.43 \\
\hline
\end{tabular}

Table 4. Chlorophyll content in leaves, mg per $1 \mathrm{~g}$ of raw material

\begin{tabular}{|c|c|c|c|c|}
\hline \multirow{2}{*}{ Chlorophyll } & \multirow{2}{*}{ Option } & \multicolumn{3}{|c|}{ Cucumber Variety } \\
\hline & & Express F1 & Forward F1 & Trapezny F1 \\
\hline \multirow[t]{2}{*}{ Chlorophyll "a" } & Control & 1.03 & 1.40 & 1.53 \\
\hline & Active & 1.81 & 1.42 & 1.67 \\
\hline \multirow[t]{2}{*}{ Chlorophyll "b" } & Control & 0.45 & 0.59 & 0.64 \\
\hline & Active & 0.70 & 0.55 & 0.68 \\
\hline \multirow{2}{*}{$\begin{array}{l}\text { Chlorophyll } \\
\text { total " } \mathrm{a}+\mathrm{b} \text { " }\end{array}$} & Control & 1.48 & 1.99 & 2.17 \\
\hline & Active & 2.51 & 1.97 & 2.25 \\
\hline \multirow{2}{*}{$\begin{array}{l}\text { Chlorophyll Ratio } \\
\text { (“a/b") }\end{array}$} & Control & 2.29 & 2.37 & 2.39 \\
\hline & Active & 2.59 & 2.58 & 2.46 \\
\hline \multirow{2}{*}{$\begin{array}{l}\text { Sum of chlorophyll } \\
\text { and carotinoids } \\
\text { (" } \mathrm{x}+\mathrm{c} \text { ") }\end{array}$} & Control & 0.21 & 0.27 & 0.32 \\
\hline & Active & 0.38 & 0.30 & 0.33 \\
\hline
\end{tabular}




\section{CONCLUSION}

From the received data it is obvious that treatment with biological preparation "NIKFAN" can strengthen plants. As a result of the treatments, cell membranes become less "leaking", that is, they are more stable and elastic. There are differences which depend on the variety. The content of pigments (chlorophyll $\mathrm{A}$ and $\mathrm{B}$ ) in the treated plants is also higher. The biopreparation Nikfan in the seed production of cucumber results in increased productivity of the plants as to the number of fruits by $39.5 \%$, the weight of the fruit by $51 \%$, and the average weight of the fruit by minimum $27 \%$.

\section{REFERENCES}

1. Nugmanova, T.A., Use of biological preparations for obtaining environmentally safe food, Collection of works of the Russian Academy of Natural Sciences "Unconventional natural resources, innovative technologies and products", No. 23, 2016, 103-107.

2. Nugmanova, T.A., Unified technology of biological toxins as the basis for industrial production of effective bacterial insecticides. Thesis, Doctor of Technical Sciences, Moscow, 1992, 389 p.
3. Nugmanova, T.A., Biopreparations - products of microbiological synthesis for the production of ecologically safe food: technology, advantages, perspectives, Ecological Aspects of Human, Animals and Plants Life, Publishing House "Belgorod", 2017, 45-76.

4. Chistyakova, L., Iion, P., Nugmanova, T.A., Shelepova, O.A., Imbia, A-M., Nikfan: Protection and Harvesting // Potatoes and Vegetables, 2016, No. 11, 20-21.

6. Nugmanova, T.A., Insecticides, fungicides and bio stimulants. Role in vegetable and potato cultivation, Potatoes and Vegetables, 2017, No. 6, 2-4.

7. Nugmanova, T.A., Gruchina, O.A., Sorokopudov, V.N., Application of biological products for crop cultivation, International Journal of Research "Advances in modern science", No. 10, Vol. 5, 2016, 128-131.

8. Lichtenthaler W., Wellburn, A.R., Determinations of total carotenoids and chlorophylls "a" and "b" of leaf extracts in different solvents. // Biochemical Society Transactions. 1983. Vol. 603. 591-592.

\title{
БИОПРЕПАРАТИ ЗА ПРОИЗВОДСТВО НА ЕКОЛОГИЧНО БЕЗОПАСНИ ХРАНИ - ЧАСТ II
}

\author{
Татяна Нугманова, Любов Чистякова, Йон Петра, Олга Шелепова, Вера Кондратиева
}

Резюме: Проучена е ефективността на биотора "Nikfan", който е един от основните биопрепарати, използвани в биологизираща система. Той е нов и модерен биопрепарат, който се оказва много ефективен за отглеждането на различни култури на открит и закрити площи. В настоящата статия като пример са представени резултатите от неговото приложение при култивиране на краставици в оранжерии. Влиянието на биопрепарата „Nikfan” върху еластичността на листата и съдържанието на хлорофил в тях също е потвърдено експериментално.

Ключови думи: биопрепарати, зеленчуци, краставици, стимулиране на растежа 
T.A. Nugmanova, DSc, Professor of Biotechnology, Academician of RANS

Director Company "BIOIN-NOVO", Moscow, Russia

e-mail: bioin@yandex.ru

L.A. Chistyakova, $\mathrm{PhD}$, Research Associate

Pumpkin Cultures Selection Group of the Selection and Seed Cultivation Center of the All-Union Research and Development Establishment, plant breeder of the Farming Enterprise "Poisk", LLC, Russia

I.K. Petra, Agronomist

Chief Technologist of the Farming Enterprise "Poisk", Russia

O.V. Shelepova, $\mathrm{PhD}$

Laboratory of Ecological Physiology and Plant Immunity, Federal State Budgetary Institution of Science Main Botanical Garden named after N.V. Tsitsina - RAS

V. Kondrat'eva, $\mathrm{PhD}$, Senior Staff Scientist

Laboratory of Ecological Physiology and Plant Immunity, Federal State Budgetary Institution of Science Main Botanical Garden named after N.V. Tsitsina - RAS. 